Tumiati LC, Allidina Y, et al. Improved heart function with myogenesis and angiogenesis after autologous porcine bone marrow stromal cell transplantation. J Thorac Cardiovasc Surg. 2002;123:1132-40. doi:10.1016/j.jtcvs.2003.03.003

\section{Coagulation, fibrinolysis, and cell activation in patients and in shed mediastinal blood during coronary artery bypass grafting with a new heparin-coated surface}

\section{To the Editor:}

Johnell and colleagues ${ }^{1}$ recently reported the improved biocompatibility of a new heparin-coated surface. They also presented results after modifications of the anticoagulation protocol. They concluded that a low dose of systemic heparin might not be sufficient to maintain the antithrombotic activity and that a high dose resulted in increased blood activation.

The design of the study merits discussion; otherwise, the conclusion might be misunderstood. In particular, the reduction of anticoagulation, even combined with a thromboresistant extracorporeal circuit, might appear detrimental for patients undergoing cardiopulmonary bypass (CPB). The basis for a safe low anticoagulation protocol in combination with heparincoated CPB circuits was described by Aldea and associates ${ }^{2}$ in 1998. It includes many parameters derived from the scientific literature from the 1990s, such as controlled suction with cell-saving devices allowing washing before retransfusion, limitation of air-blood contact with closed circuits, specifically adapted anticoagulation through precise heparin and protamine titration, low prime volume facilitated by retrograde autologous prime, and normothermia. This tailored approach of CPB, adopted by our own center, has been found clinically beneficial ${ }^{3}$ and is therefore justified for routine surgical practice. One of the most important parameters omitted by the authors in the management of a low heparinized CPB is the retransfusion of highly activated blood into the circulation because cardiotomy suction has been used. The contact of blood with air or with the surgical field through the tissue pathway is followed by activation of inflammation and hemostasis disturbances, despite the use of a significant amount of fluid heparin, which appears to be an unperfected anticoagulant for CPB although it is universally used. When a cell-saving device is used instead of cardiotomy suction, all the different markers of blood activation are excluded and not retransfused into the circulation. With this approach, it has been proved that circulating $\mathrm{F}_{1+2}$ levels do not correlate with activated clotting time (the lowest activated clotting time does not imply the highest $\mathrm{F}_{1+2}$ ) and that a low anticoagulation protocol is safe for the patient. ${ }^{2}$ Therefore some of the results presented by Johnell and colleagues ${ }^{1}$ need to be taken with caution.

On the other hand, the study of Johnell and colleagues ${ }^{1}$ provides important data about the detrimental effects of heparin, which could justify a low anticoagulation protocol. Evidence of proinflammatory and procoagulant effects of high-dose heparin was found, as in previous reports. The reduction of heparin dose during CPB with heparin-coated circuits reduces leukocyte adhesion on artificial surfaces ${ }^{4}$ and better preserves antithrombin III levels. ${ }^{5}$ In addition, low anticoagulation requires a low dose of protamine for titration and reduces the amount of heparin-protamine complexes known to activate the classic pathway of complement cascade.

The biocompatibility of new equipment must be assessed, particularly with respect to thromboresistance. Johnell and colleagues ${ }^{1}$ successfully demonstrated the reduction of contact activation. However, it is fundamental that the experimental design respect some principles that have been previously elucidated when they are expected to be of major importance in the outcome. This is particularly true if CPB is managed with low anticoagulation.

Christophe Baufreton, MD, PhD Jean Louis de Brux, MD Department of Cardiac Surgery University Hospital of Angers Angers, France

\section{References}

1. Johnell M, Elgue G, Larsson R, Larsson A, Thelin S, Siegbahn A. Coagulation, fibrinolysis, and cell activation in patients and shed mediastinal blood during coronary artery bypass grafting with a new heparin-coated surface. J Thorac Cardiovasc Surg. 2002;124: 321-32.

2. Aldea GS, O'Gara P, Shapira OM, Treanor P, Osman A, Patalis E, et al. Effect of anticoagulation protocol on outcome in patients undergoing $\mathrm{CABG}$ with heparin-bonded cardio- pulmonary bypass circuits. Ann Thorac Surg. 1998;65:425-33.

3. Baufreton C, de Brux JL, Binuani P, Corbeau JJ, Subayi JB, Daniel JC, et al. A combined approach for improving cardiopulmonary bypass in coronary artery surgery: a pilot study. Perfusion. 2002;17:407-13.

4. Nakajima T, Kawazoe K, Ishibashi K, Kubota Y, Sasaki T, Izumoto H, et al. Reduction of heparin dose is not beneficial to platelet function. Ann Thorac Surg. 2000;70:186-90.

5. Ranucci M, Cazzaniga A, Soro G, Isgro G, Frigiola A, Menicanti L. The antithrombin III-saving effect of reduced systemic heparinization and heparin-coated circuits. J Cardiothorac Vasc Anesth. 2002;16:31620.

doi:10.1016/j.jtcvs.2003.07.022

\section{Myogenesis after myocardial stem cell transplantation}

\section{To the Editor:}

I read the article of Chedrawy and colleagues, "Incorporation and Integration of Implanted Myogenic and Stem Cells Into Native Myocardial Fibers: Anatomic Basis for Functional Improvements," in the Journal with great interest. Chedrawy and colleagues ${ }^{1}$ described regenerated isogenic myofebrile grafts injected into nonischemic normal myocardium. By 4 to 6 weeks, fully differentiated myocytes could be seen to interconnect among native cardiomyocytes. The authors attributed this desirable incorporation to cell-cell electromechanical junction. However, in a clinical setting with scar tissue and akinetic ventricular wall, the microenvironment is not conducive to electromechanical activity to induce a desirable environment to trigger phenotypic changes for transplanted cells. Is it possible that cytokines, such as transforming growth factor $\beta$ or insulin growth factor, generated because of the presence of macrophage and monocytes, play a role in the genesis of proliferation and transformation of new myofibrils?

$$
\begin{array}{r}
\text { Syde Taheri, MD } \\
9095 \text { Main St } \\
\text { Suite C } \\
\text { Clarence, NY } 14031
\end{array}
$$

\section{Reference}

1. Chedrawy EG, Wang JS, Nguyen DM, Shum-Tim D, Chiu RC. Incorporation and integration of implanted myogenic and stem 